\title{
Sorghum growth in soil treated with sewage sludge from the textile industry
}

\author{
W. J. Melo ${ }^{1,2}$, G. M. P. Melo ${ }^{3}$, V. P. Melo ${ }^{3}$, M. M. Yada ${ }^{1,2}$, \\ R. S. Carlos ${ }^{4} \&$ E. G. Silva ${ }^{4}$ \\ ${ }^{1}$ Departamento de Tecnologia, \\ Faculdade de Ciências Agrárias e Veterinárias, UNESP, Brazil \\ ${ }^{2}$ The Brazilian National Council for Scientific and \\ Technological Development (CNPq), Brazil \\ ${ }^{3}$ Universidade Camilo Castelo Branco, UNICASTELO, Brazil \\ ${ }^{4}$ Faculdade de Tecnologia Nilo de Stéfani, FATEC, Brazil
}

\begin{abstract}
Sewage sludge (SS), a residue from wastewater treatment can be a hazard to the environment because it may contain trace elements and other toxic substances. But it is also rich in organic matter and plant nutrients so that an attractive destination for the residue is its use in agriculture as fertilizer and soil conditioner. The aim of this work was to evaluate the effect of doses of SS from the textile industry on sorghum plant growth. The experiment was carried out under greenhouse conditions using typic Haplorthox soil occurring at Jaboticabal, SP, Brazil. The experiment design was totally randomized with 7 treatments (absolute control, without fertilization and SS, mineral control, with mineral fertilization based on soil analysis, 7, 14, 21, 28 and $35 \mathrm{t} \mathrm{ha}^{-1} \mathrm{SS}$, dry basis) in 3 replications and sorghum as the test plant. At the end of the plant cycle, plant dry matter and grain production were estimated, and soil samples were analyzed for soil chemical fertility. Textile sewage sludge improved soil fertility, except in relation to $\mathrm{K}$ and $\mathrm{Mg}$, plant dry matter and grain production. It also caused symptoms of K deficiency and other symptoms of unknown origin. The SS rates caused the same grain production and the highest doses caused delay in the panicle emission.

Keywords: biosolid, soil fertility, dry matter, grain production, wastewater, sewer, fertilization, pollution.
\end{abstract}




\section{Introduction}

The human need for food and for other goods, such as clothes is increasing, resulting in the production of great volumes of wastewater. There is concern about environmental quality claims for the treatment of the wastewater before it is returned to the water resources, resulting in a production of a residue called sewage sludge (SS).

The final disposition of sewage sludge also offers a risk to the environment, plant, animal and human health because it contains trace elements (Andrade et al. [1]) and toxic organic substances and pathogenic organisms (Sidihu and Toze [2]) in different concentrations and combinations. It also attracts insects and other disease transmitters.

The composition of sewage sludge depends on the origin of the sewer. Sewage sludge produced from a domestic sewer is normally poor in trace elements, but may contain pathogenic components, such as helminth eggs. On the other hand, sewage sludge obtained from the treatment of industrial wastewater normally contains trace elements and toxic organic substances. If textile industries were involved, it may also contain dyes and other products used in the production of fibers and clothes.

Because sewage sludge contains organic matter and other plant nutrients, such as nitrogen and phosphorus, and micronutrients, such as zinc, attention has been given for its use in agriculture as a fertilizer or soil conditioner. Some studies have already shown that it improves soil fertility, plant growth and production.

The aim of this work was to evaluate the effect of rates of sewage sludge obtained by treating wastewater from the textile industry on soil fertility, growth and grain production by sorghum plants. The hypothesis is that the residue, supplemented with $\mathrm{N}, \mathrm{P}$ and $\mathrm{K}$, may improve soil fertility and sorghum plant growth.

\section{Methodology}

The experiment was carried out in pots under greenhouse conditions at Faculdade de Ciências Agrárias e Veterinárias, Jaboticabal, SP, Brazil (21 ${ }^{\circ} 15^{\prime} 22^{\prime}$ ' S, 48 $15^{\circ} 18^{\prime \prime} \mathrm{W}, 610 \mathrm{~m}$ altitude).

The experimental design comprised randomized blocks with seven treatments $(\mathrm{AC}=$ absolute control, without fertilization and $\mathrm{SS}, \mathrm{MC}=$ mineral control, with mineral fertilization based on soil chemical analysis, D1, D2, D3, D4, D5=7, 14, 21,28 and $35 \mathrm{t} \mathrm{ha}^{-1} \mathrm{SS}$, dry weight basis) in 3 replications. The dose $7 \mathrm{t} \mathrm{ha}^{-1}$ was calculated according to CONAMA [4].The fertilization of the MC was undertaken based on soil chemical analysis and the indications for sorghum crop in São Paulo State (Raij et al. [5]). The fertilizers, ammonium sulphate, simple superphosphate and potassium chloride, were split three times, sowing, 20 and 45 days after sowing (Table 1). The treatments with SS received NPK fertilization, when necessary, in order to reach the same NPK content in the MC (Table 2). 
Table 1: $\quad$ Fertilization applied to the mineral control (MC).

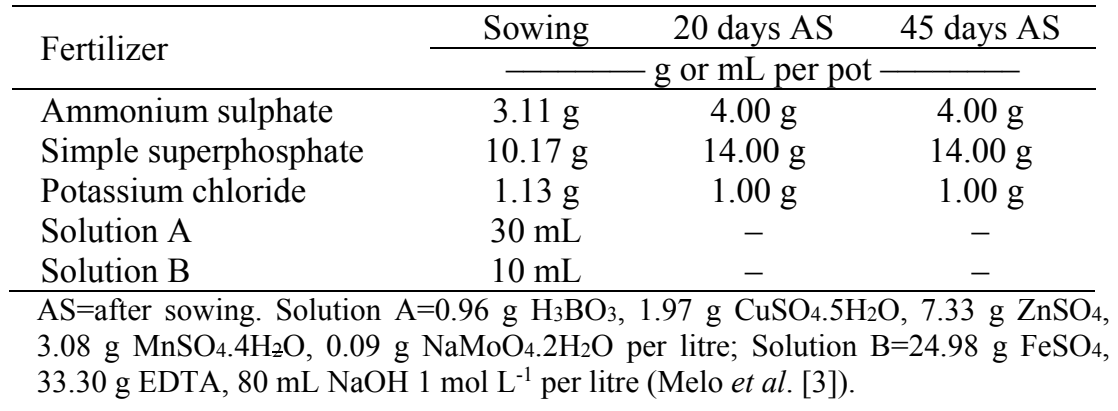

Table 2: Mineral fertilization applied to the treatments that received sewage sludge.

\begin{tabular}{lccccc}
\hline \multirow{2}{*}{ Treatment } & $\mathrm{D} 1$ & $\mathrm{D} 2$ & $\mathrm{D} 3$ & $\mathrm{D} 4$ & $\mathrm{D} 5$ \\
\cline { 2 - 5 } Fertilizer & \multicolumn{5}{c}{ g pot $^{-1}$} \\
\cline { 2 - 5 } & \multicolumn{5}{c}{ Sowing } \\
\hline Ammonium sulphate & 2.32 & - & - & - & - \\
Simple superphosphate & 17.90 & 17.62 & 17.35 & 17.08 & 16.80 \\
Potassium chloride & 1.06 & 0.99 & 0.92 & 0.85 & 0.79 \\
& \multicolumn{5}{c}{$\mathbf{2 0}$ days after sowing } \\
Ammonium sulphate & - & - & - & - & \\
Simple superphosphate & 10.00 & 10.00 & 10.00 & 10.00 & 10.00 \\
Potassium chloride & 1.00 & 1.00 & 1.00 & 1.00 & 1.00 \\
& \multicolumn{5}{c}{$\mathbf{2 0}$ days after sowing } \\
Ammonium sulphate & - & - & - & - & - \\
Simple superphosphate & 10.00 & 10.00 & 10.00 & 10.00 & 10.00 \\
Potassium chloride & 1.00 & 1.00 & 1.00 & 1.00 & 1.00 \\
\hline \multicolumn{2}{c}{ D1, D2, D3, D4, D5=7, 14, 21, 28 and 35 t ha ${ }^{-1}$ SS, respectively (dry weight basis). }
\end{tabular}

The soil, a typic Haplorthox, was collected at Jaboticabal $\left(21^{\circ} 15^{\prime} 22^{\prime \prime} \mathrm{S}\right.$, $48^{\circ} 15^{\prime} 18^{\prime \prime} \mathrm{W}, 610 \mathrm{~m}$ altitude) from the top $0-0.20 \mathrm{~m}$, air dried and sieved to $2 \mathrm{~mm}$ for chemical analysis and to $5 \mathrm{~mm}$ for filling pots with $10 \mathrm{~kg}$ capacity. Its chemical composition was organic matter $=14.0 \mathrm{mg} \mathrm{dm}^{-3}, \mathrm{pH}\left(\mathrm{CaCl}_{2} 0.05 \mathrm{~mol} \mathrm{~L}^{-}\right.$ $\left.{ }^{1}\right)=5.6, \quad$ P-resin $=10.0 \quad \mathrm{mg} \mathrm{dm}{ }^{-3}, \quad \mathrm{~K}=1.2 \quad$ mmolc $_{\mathrm{c}} \quad \mathrm{dm}^{-3}, \quad \mathrm{Ca}=19.0 \quad \mathrm{mmol}_{\mathrm{c}}$ $\mathrm{dm}^{-3}, \mathrm{Mg}=14.0 \mathrm{mmol}_{\mathrm{c}} \mathrm{dm}^{-3}, \mathrm{H}+\mathrm{Al}=15.0 \quad \mathrm{mmol}_{\mathrm{c}} \mathrm{dm}^{-3}, \mathrm{CEC}=49.0 \mathrm{mmol}_{\mathrm{c}}$ $\mathrm{dm}^{-3}, \mathrm{~V}=70,0 \%{ }^{1}$ (air dried basis).

Sewage sludge (SS) was supplied by Riovivo Ambiental Ltda situated in Brusque, Santa Catarina State, Brazil. It is a water and wastewater treatment station that receives domestic and industrial sewer. The sewage sludge used in the experiment presented organic carbon $=37.19 \%, \mathrm{~N}=5.42 \%, \mathrm{P}=2.10 \%$, $\mathrm{K}=1.41 \%, \mathrm{Ca}=0.50 \%, \mathrm{Mg}=0.21 \%, \mathrm{~S}=0.74 \%, \mathrm{Cu}=52.07 \mathrm{mg} \mathrm{kg}^{-1}, \mathrm{Fe}=5,360.00$ 
$\mathrm{mg} \mathrm{kg}{ }^{-1}, \mathrm{Mn}=965.83 \mathrm{mg} \mathrm{kg}^{-1}, \mathrm{Zn}=241.67 \mathrm{mg} \mathrm{kg}^{-1}, \mathrm{~B}=158.28 \mathrm{mg} \mathrm{kg}^{-1}, \mathrm{Mo}=2.84$ $\mathrm{mg} \mathrm{kg}{ }^{-1}, \mathrm{As}=0.021 \mathrm{mg} \mathrm{kg}^{-1}, \mathrm{Se}=0.056 \mathrm{mg} \mathrm{kg}{ }^{-1}, \mathrm{Hg}=0.87 \mathrm{mg} \mathrm{kg}^{-1}, \mathrm{Ba}=16.89$ $\mathrm{mg} \mathrm{kg}{ }^{-1}, \mathrm{Cd}=2.30 \mathrm{mg} \mathrm{kg}^{-1}, \mathrm{~Pb}=22.93 \mathrm{mg} \mathrm{kg}^{-1}, \mathrm{Ni}=12.83 \mathrm{mg} \mathrm{kg}^{-1}, \mathrm{Cr}=66.73 \mathrm{mg}$ $\mathrm{kg}^{-1}$ (dried weight basis).

The plant test was sorghum [Sorghum bicolor (L) Moench], saccharine hybrid DKB 550, whose seeds had been previously germinated in washed sand.

Liming was not necessary because the bases' saturation (V\%) was 70\%. The soil, the fertilizers and the SS were strongly mixed and used to fill plastic pots with $10 \mathrm{~kg}$ capacity. Water was added to rich $70 \%$ of the soil water holding capacity (WHC) and five sorghum seedlings were transplanted in each pot. Irrigations were carried out daily in order to replace the water lost by evapotranspiration. When the plants were about $10 \mathrm{~cm}$ high, four plants were removed from each pot and the one remaining in the pot was grown until the plants were harvested.

When the sorghum grain moisture was about $17 \%$, the plants were cut at the soil surface and shoot and roots were sampled. Shoots and roots were washed in $\mathrm{HCl} 0.01 \mathrm{~mol} \mathrm{~L}^{-1}$, tap water and deionized water, dried at $70^{\circ} \mathrm{C}$ in an oven dotted with air circulation, weighed, milled in a Willey mill and stored for further analysis. The soil was removed from the pots, air dried, sieved to $2 \mathrm{~mm}$ and analyzed for chemical attributes of soil fertility (Raij et al. [5]).

The data were submitted to ANOVA analysis, and when the F test was significant at $5 \%$ or less the Tukey test was used for means comparison (Pimentel-Gomes and Garcia [6]). The software Assistat was used for the statistical analysis (Silva [7]).

\section{Results and discussion}

Apart from $\mathrm{Mg}$, the other soil chemical properties were significantly affected by the treatments (Tables 3 and 4). The absence of effects on soil Mg probably was due to the low concentration of the nutrient in SS, the concentration already present in the soil and its absorption by the plants. Magnesium concentration in the soil was higher than 8 mmolc dm $\mathrm{dm}^{-3}$; a value considered too high for the soils in São Paulo State (Raij et al. [5]). In an experiment using 4, 8, 12 and $16 \mathrm{tha}^{-1}$ $\mathrm{SS}$ and cropped with sorghum, soil Mg concentration increased in samples collected 120 days after sowing in the treatments amended with the residue (Melo et al. [8]). In this work, $\mathrm{Mg}$ concentration in SS was $5.8 \mathrm{~g} \mathrm{~kg}^{-1}$.

Only the treatment $\mathrm{AC}$, which presented the lowest value, $\mathrm{K}$ differed from the other treatments, which did not differ among themselves. In the treatments receiving $\mathrm{SS}$, the concentration of this nutrient in the soil varied in the range 1.63-2.20 $\mathrm{mmol}_{\mathrm{c}} \mathrm{dm}^{-3}$, values considered medium for soils in São Paulo State (Raij et al. [5]). In the treatments amended with SS, sorghum plants presented symptoms of K deficiency (Figure 1). 
Table 3: Phosphorus, extracted by resin, potassium, calcium and magnesium in a typic Haplorthox treated with rates of textile sewage sludge and cropped with sorghum.

\begin{tabular}{lcccc}
\hline \multirow{2}{*}{ Treatments } & P resin & $\mathrm{K}$ & $\mathrm{Ca}$ & $\mathrm{Mg}$ \\
\cline { 2 - 5 } & $\mathrm{mg} \mathrm{dm} \mathrm{dm}^{-3}$ & \multicolumn{3}{c}{ mmolc dm $^{-3}$} \\
\hline $\mathrm{AC}$ & $12.00 \mathrm{~d}$ & $0.70 \mathrm{~b}$ & $20.33 \mathrm{~b}$ & $12.67 \mathrm{a}$ \\
$\mathrm{MC}$ & $74.33 \mathrm{~cd}$ & $2.30 \mathrm{a}$ & $20.33 \mathrm{~b}$ & $11.33 \mathrm{a}$ \\
$7 \mathrm{t} \mathrm{ha}^{-1} \mathrm{SS}$ & $120.67 \mathrm{bc}$ & $2.20 \mathrm{a}$ & $28.33 \mathrm{ab}$ & $18.67 \mathrm{a}$ \\
$14 \mathrm{t} \mathrm{ha}^{-1} \mathrm{SS}$ & $143.00 \mathrm{bc}$ & $1.73 \mathrm{a}$ & $26.33 \mathrm{ab}$ & $13.33 \mathrm{a}$ \\
$21 \mathrm{t} \mathrm{ha}^{-1} \mathrm{SS}$ & $163.33 \mathrm{abc}$ & $1.63 \mathrm{a}$ & $28.66 \mathrm{ab}$ & $14.00 \mathrm{a}$ \\
$28 \mathrm{t} \mathrm{ha}^{-1} \mathrm{SS}$ & $246.67 \mathrm{a}$ & $1.76 \mathrm{a}$ & $32.67 \mathrm{a}$ & $18.00 \mathrm{a}$ \\
$35 \mathrm{t} \mathrm{ha}^{-1} \mathrm{SS}$ & $178.00 \mathrm{ab}$ & $1.97 \mathrm{a}$ & $30.33 \mathrm{a}$ & $15.67 \mathrm{a}$ \\
\hline $\mathrm{CV}(\%)$ & 26.87 & 1.37 & 12.44 & 1.96 \\
\hline
\end{tabular}

$\mathrm{AC}=$ absolute control. $\mathrm{MC}=$ mineral fertilization control. $\mathrm{SS}=$ sewage sludge. $\mathrm{CV}=$ coefficient of variation. $\mathrm{CEC}=$ cation exchange capacity. $\mathrm{V} \%=$ bases saturation. Means followed by the same letters are not different by the Tukey test at $5 \%$.

Table 4: Organic matter, $\mathrm{pH}$ and potential acidity in a typic Haplorthox treated with rates of textile sewage sludge and cropped with sorghum.

\begin{tabular}{lccc}
\hline \multirow{2}{*}{ Treatment } & $\mathrm{OM}$ & $\mathrm{pH}$ & $\mathrm{H}+\mathrm{Al}$ \\
\cline { 2 - 4 } & $\mathrm{g} \mathrm{dm}^{-3}$ & $\mathrm{CaCl}_{2}$ & $\mathrm{mmol}_{\mathrm{c}} \mathrm{dm}^{-3}$ \\
\hline $\mathrm{AC}$ & $20.67 \mathrm{c}$ & $5.47 \mathrm{a}$ & $20.67 \mathrm{~d}$ \\
$\mathrm{MC}$ & $22.67 \mathrm{~b}$ & $4.27 \mathrm{c}$ & $47.00 \mathrm{a}$ \\
$7 \mathrm{t} \mathrm{ha}^{-1} \mathrm{SS}$ & $22.33 \mathrm{bc}$ & $5.37 \mathrm{a}$ & $26.00 \mathrm{c}$ \\
$14 \mathrm{t} \mathrm{ha}^{-1} \mathrm{SS}$ & $23.33 \mathrm{~b}$ & $5.43 \mathrm{a}$ & $25.00 \mathrm{c}$ \\
$21 \mathrm{t} \mathrm{ha}^{-1} \mathrm{SS}$ & $23.66 \mathrm{~b}$ & $5.33 \mathrm{ab}$ & $26.00 \mathrm{c}$ \\
$28 \mathrm{t} \mathrm{ha}^{-1} \mathrm{SS}$ & $25.67 \mathrm{a}$ & $5.37 \mathrm{a}$ & $26.00 \mathrm{c}$ \\
$35 \mathrm{t} \mathrm{ha}^{-1} \mathrm{SS}$ & $25.67 \mathrm{a}$ & $5.13 \mathrm{~b}$ & $30.00 \mathrm{~b}$ \\
\hline $\mathrm{CV}(\%)$ & 2.95 & 1.51 & 4.81 \\
\hline
\end{tabular}

$\mathrm{AC}=$ absolute control. $\mathrm{MC}=$ mineral fertilization control. $\mathrm{SS}=$ sewage sludge. $\mathrm{CV}=$ coefficient of variation. $\mathrm{OM}=$ organic matter. Means followed by the same letters are not different by the Tukey test at $5 \%$.

Phosphorus extracted by resin increased with the rates of SS, but no significant difference was detected in the three highest ones. The nutrient concentration in the soil ranged from $12.00 \mathrm{mg} \mathrm{dm}^{-3}$ (treatment AC) to 246.67 $\mathrm{mg} \mathrm{dm}{ }^{-3}$ (treatment receiving $28 \mathrm{t} \mathrm{ha}^{-1} \mathrm{SS}$ ). All the treatments amended with SS presented $\mathrm{P}$ values considered too high (Raij et al. [5]).

Calcium soil concentration was higher in the two highest SS rates, and differences between treatments were observed only when comparing the two highest rates of SS with the controls $\mathrm{AC}$ and $\mathrm{MC}$. The treatments amended with $\mathrm{SS}$ were not different in relation to soil $\mathrm{Ca}$ concentration. The data obtained for 
$\mathrm{Ca}$ in all the treatments were higher than $7 \mathrm{mmol}_{\mathrm{c} \mathrm{kg}}{ }^{-1}$, considered high for soils in São Paulo State.

As expected, SS promoted an increase in the soil concentration of organic matter, but only the two highest rates differed from the controls and from the other doses of the residue. This increase in soil organic matter, phosphorus and calcium due to SS application has been observed by other authors (Melo et al. [8]).
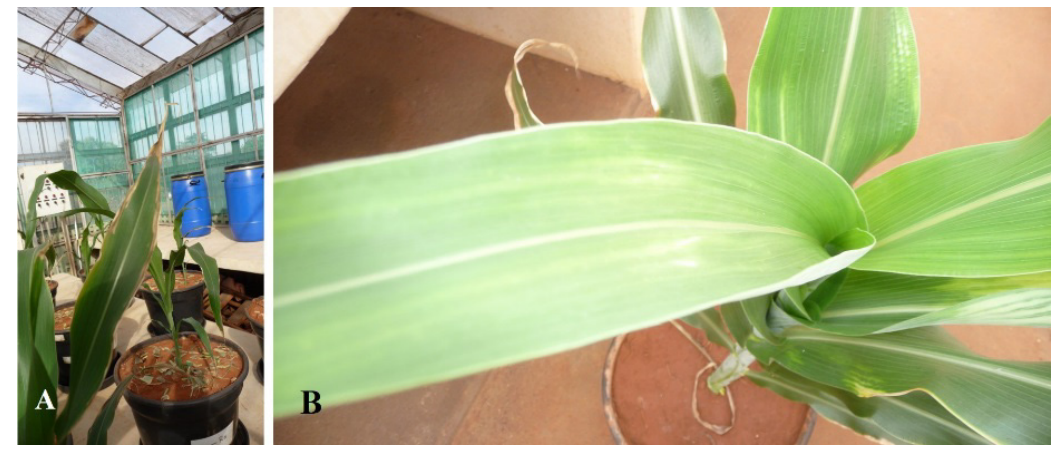

Figure 1: Potassium deficiency (A) and unknown symptoms (B) in sorghum plants grown in a typic Haplorthox treated with rates of textile sewage sludge.

The $\mathrm{pH}$ in $\mathrm{CaCl}_{2} 0.05$ mol L-1 was lower in the mineral control due to the application of ammonium sulphate as a fertilizer. The treatments amended with sewage sludge did not differ from the absolute control, except those receiving the highest dose of the residue, where $\mathrm{pH}$ was lower. This finding does not agree with work that found an increase in soil $\mathrm{pH}$ by the amendment with SS (Hoyl and Turner [10]). Increase that is attributed to the presence of basic cations $\left(\mathrm{K}^{+}\right.$, $\mathrm{Ca}^{2+}, \mathrm{Mg}^{2+}$ ) and soluble-C (Francini et al. [11]). However, the production of carbonic gas and protons during the decomposition of the organic matter may produce a decrease in soil $\mathrm{pH}$ (Miyasawa et al. [12]). The lowest $\mathrm{H}+\mathrm{Al}$ concentration in soil occurred in the $\mathrm{AC}$ treatment and the highest was observed in the $\mathrm{MC}$ treatment. Comparing the treatments that received SS, the highest concentration of $\mathrm{H}+\mathrm{Al}$ was observed in the treatment receiving $35 \mathrm{t} \mathrm{ha}^{-1} \mathrm{SS}$ and the other doses were not different among them.

Sorghum plants grew and produced grains in all the treatments (Table 5, Figure 2), but those in the treatments receiving SS presented symptoms of $\mathrm{K}$ deficiency (Figure 1). Other symptoms were also observed in the plants cropped in the pots where soil was amended with SS, but the analysis of soil and plants did not permit us to conclude which element was responsible for them (Figure 1).

As discussed above, SS improved soil fertility, except in relation to $\mathrm{K}$ and $\mathrm{Mg}$, improving plant growth and grain production, which was the same as the MC treatment, which was fertilized based on soil chemical analysis. 
Table 5: Sorghum dry matter and grain production when cropped in a typic Haplorthox treated with rates of textile sewage sludge.

\begin{tabular}{|c|c|c|c|}
\hline \multirow{2}{*}{ Treatment } & Root & Shoot & Grain \\
\hline & \multicolumn{3}{|c|}{$\longrightarrow$ g plant $^{-1}$} \\
\hline $\mathrm{AC}$ & $15.30 \mathrm{~b}$ & $31.93 \mathrm{c}$ & $14.22 \mathrm{~b}$ \\
\hline $\mathrm{MC}$ & $19.67 \mathrm{ab}$ & $33.77 \mathrm{c}$ & $42.06 \mathrm{a}$ \\
\hline $7 \mathrm{t} \mathrm{ha}^{-1} \mathrm{SS}$ & $20.88 \mathrm{ab}$ & $40.50 \mathrm{bc}$ & $41.80 \mathrm{a}$ \\
\hline $14 \mathrm{t} \mathrm{ha}^{-1} \mathrm{SS}$ & $22.03 \mathrm{ab}$ & $43.77 \mathrm{ab}$ & $44.77 \mathrm{a}$ \\
\hline $21 \mathrm{t} \mathrm{ha}^{-1} \mathrm{SS}$ & $23.92 \mathrm{ab}$ & $44.10 \mathrm{ab}$ & $39.91 \mathrm{a}$ \\
\hline $28 \mathrm{t} \mathrm{ha}^{-1} \mathrm{SS}$ & $24.43 \mathrm{a}$ & $48.70 \mathrm{ab}$ & $43.02 \mathrm{a}$ \\
\hline $35 \mathrm{t} \mathrm{ha}^{-1} \mathrm{SS}$ & $24.80 \mathrm{a}$ & $51.13 \mathrm{a}$ & $40.26 \mathrm{a}$ \\
\hline $\mathrm{CV}(\%)$ & 14.80 & 8.11 & 13.18 \\
\hline
\end{tabular}
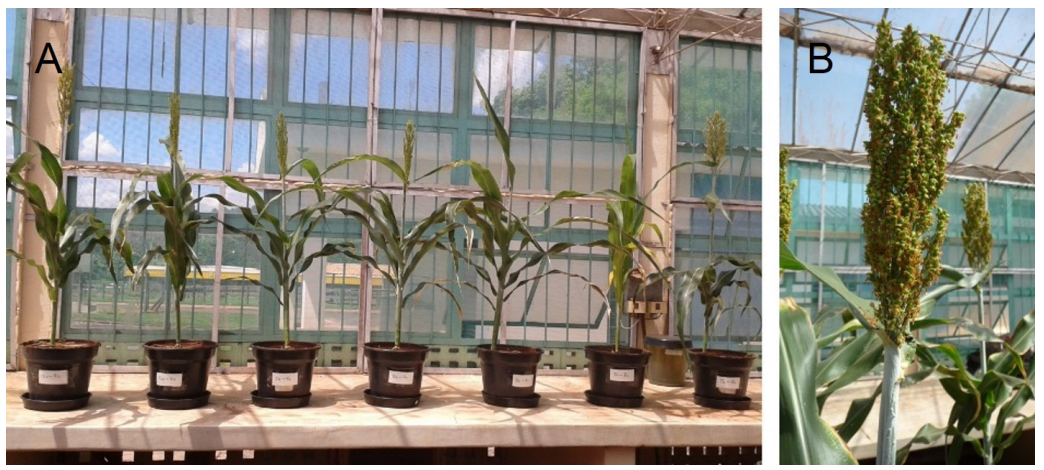

Figure 2: General view of the experiment. From right to left: absolute control, mineral control, 7, 14, 21, 28 and $35 \mathrm{t} \mathrm{ha}^{-1}$ sewage sludge (A) and sorghum panicle of the treatment $35 \mathrm{tha}^{-1}$ sewage sludge (B).

The treatments which received the highest rates of sewage sludge were the latter for panicle emission and presented more vigorous growth (dry mass production).

\section{Conclusion}

Textile sewage sludge improved soil fertility except in relation to $\mathrm{K}$ and $\mathrm{Mg}$, so that the plants cropped in the treatments with soil amended with the residue presented symptoms of $\mathrm{K}$ deficiency.

All the rates of textile sewage sludge tested $\left(7,14,21,28\right.$ and $35 \mathrm{t} \mathrm{ha}^{-1}$, dry weight basis), completed with NPK in order to contain the same NPK composition of the treatment receiving mineral fertilization based on soil 
chemical analysis, produced the same grains quantity of the control fertilized with mineral NPK.

Textile sewage sludge promoted a delay in the panicle emission and unknown symptoms in the leaves.

\section{Acknowledgements}

The authors thank Conselho Nacional de Desenvolvimento Científico e Tecnológico $(\mathrm{CNPq})$ and Fundação de Apoio à Pesquisa, Ensino e Extensão (FUNEP), for the scholarships, and Riovivo Ambiental Ltda, for the financial support.

\section{References}

[1] Andrade, M.G., Lima, A.S.T., Melo, W.J., Santos, E.J., Herrmann, A.B. Elementos-traço em dois latossolos após aplicações anuais de lodo de esgoto por treze anos. Semina: Ciências Agráras, 35(1), pp. 135-148, 2014.

[2] Sidihu, J.P.S. \& Toze, S.G. Human pathogens and their indicators in biosolids: A literature review. Environment International, 35(1), pp. $187-$ 201, 2009.

[3] Melo, W.J., Melo, G.M.P., Melo, V.P., Bertipaglia, L.M.A. Experimentação sob condições controladas. FUNEP, Jaboticabal, SP, 1998, 86 p.

[4] CONAMA (Conselho Nacional do Meio Ambiente). Resolução 375, Critérios e procedimentos para o uso agrícola de lodos de esgoto gerados em estações de tratamento de esgoto sanitário e seus produtos derivados. Brasília, 2006.

[5] Raij, B. van, Cantarella, H. Milho. In: Raij, B. van, Cantarella, H., Quaggio, J. A., Furlani, A. M. C. Recomendação de adubação e calagem para o Estado de São Paulo. 2. ed. Campinas: Instituto Agronômico, pp. 56-59. 1997. (Boletim Técnico 100).

[6] Pimentel-Gomes, F., Garcia, C. H. Estatística aplicada a experimentos agronômicos e florestais: Exposição com exemplos e orientações para uso de aplicativos. Piracicaba: FEALQ, 2002, 309 p.

[7] Silva, F.A.S. Assistat, versão 7.6 beta. Canpina Grande, PB, Brasil, 2013.

[8] Melo, W.J., Marques, M.O., Ferreira, M.E., Melo, G.M.P., Melo, V.P. Chemical properties and enzyme activity in a sewage sludge treated soil. Comm. in Soil Sci. and Plant Anal., 33(9, 10), pp. 1643-1659, 2002.

[9] Diacono, M. \& Montemurro, F. Long-term effects of organic amendments on soil fertility. A review. Agron. Sustain. Dev. 30, pp. 401-422, 2010.

[10] Hoyl, P.B. \& Turner, R.C. Effect of organic materials added to very acid soils on pH, aluminum, exchangeable NH4 and crop yields. Soil Science, 9, pp. 227-237, 1975. 
[11] Francini, J.C., Malavolta, E., Miyasawa, M., Pavan, M.A. Alterações químicas em solos ácidos após a aplicação de resíduos vegetais. $R$. bras. Ci. Solo, 23, pp. 533-542, 1999.

[12] Miyasawa, M., Pavan, M.A., Francini, J.C. Neutralização da acidez do perfil do solo por resíduos vegetais. Inf. Agron., 92, pp. 1-8, 2000, (encarte técnico). 